\title{
Formononetin induces apoptotic cell death through the suppression of mitogen-activated protein kinase and nuclear factor-kB phosphorylation in FaDu human head and neck squamous cell carcinoma cells
}

\author{
JI-SU OH ${ }^{1}$, TAE-HYEON KIM ${ }^{2}$, JONG-HYUN PARK ${ }^{2}$, HYANGI LIM ${ }^{2}$, IN-A CHO ${ }^{2}$, JAE-SEEK YOU ${ }^{1}$, \\ GYEONG-JE LEE ${ }^{3}$, YO-SEOB SEO ${ }^{4}$, DO KYUNG KIM ${ }^{2}$, CHUN SUNG KIM ${ }^{2}$, SUN-KYOUNG YU ${ }^{2}$, \\ HEUNG-JOONG KIM ${ }^{2}$, SU-GWAN KIM ${ }^{1}$ and JAE-SUNG KIM ${ }^{2}$ \\ ${ }^{1}$ Department of Oral and Maxillofacial Surgery; ${ }^{2}$ The Institute of Dental Science; ${ }^{3}$ Department of Prosthodontics; \\ ${ }^{4}$ Department of Oral and Maxillofacial Radiology, School of Dentistry, Chosun University, \\ Dong-gu, Gwang-Ju 61452, Republic of Korea
}

Received May 3, 2019; Accepted October 25, 2019

DOI: 10.3892/or.2019.7432

\begin{abstract}
Formononetin, a phytoestrogen extracted from various herbal plants, has been investigated as an anticancer agent against diverse types of cancer. The aim of the present study was to investigate the induction of apoptotic cell death by formononetin in the FaDu pharyngeal squamous cell carcinoma cell line. Formononetin significantly increased FaDu cell death, with an estimated $\mathrm{IC}_{50}$ value of $50 \mu \mathrm{M}$; however, it did not affect the viability of normal L929 mouse fibroblasts used as normal control at 5-25 $\mu \mathrm{M}$. Typical characteristics
\end{abstract}

Correspondence to: Professor Jae-Sung Kim, The Institute of Dental Science, School of Dentistry, Chosun University, 309 Philmun-daero, Dong-gu, Gwang-Ju 61452, Republic of Korea E-mail: js_kim@chosun.ac.kr

Abbreviations: HNSCC, head and neck squamous cell carcinoma; T. pratense, Trifolium pratense; ATCC, American Type Culture Collection; FBS, fetal bovine serum; OD, optical density; $\mathrm{H} \& \mathrm{E}$, hematoxylin and eosin; PBS, phosphate-buffered saline; DAPI, 4',6-diamidino-2-phenylindole dihydrochloride; FACS, fluorescence-activated cell sorting; PI, propidium iodide; SDS-PAGE, sodium dodecyl sulfate polyacrylamide gel electrophoresis; FasL, Fas ligand; Bid, Bax-like BH3 protein; tBid, truncated Bid; Bcl-2, B-cell lymphoma-2; Bcl-xL, B-cell lympoma-extra large; Bik, Bcl-2 interacting killer; Bim, Bcl-2-like protein 11; PARP, poly(ADP-ribose) polymerase; ERK, extracellular signal-regulated kinase; JNK, c-Jun N-terminal kinase; NF- $\mathrm{BB}$, nuclear factor- $\kappa \mathrm{B}$; MAPK, mitogen-activated protein kinase; FADD, Fas-associated death domain; TNF, tumor necrosis factor; TRADD, TNF-receptor-associated death domain; TRAIL, TNF-related apoptosis-inducing ligand; Bax, Bcl-2-associated $\mathrm{X}$ protein; Bak, Bcl-2-antagonist/killer

Key words: formononetin, apoptosis, human head and neck squamous cell carcinoma, chemotherapy of apoptosis, such as morphological alterations, chromatin condensation, DNA fragmentation and the size of the apoptotic cell population, were increased in FaDu cells treated with formononetin for $24 \mathrm{~h}$. Furthermore, formononetin-induced FaDu cell death involved the death receptor-mediated extrinsic and the mitochondria-dependent intrinsic apoptotic pathways by activating the caspase cascade. The chemotherapeutic effects of formononetin were mediated by the suppression of mitogen-activated protein kinases, including extracellular signal-regulated kinase $1 / 2$ and p38, and nuclear factor- $\kappa \mathrm{B}$ phosphorylation in $\mathrm{FaDu}$ cells. Finally, the oral administration of formononetin decelerated tumor growth through the expression of cleaved caspase- 3 in a $\mathrm{FaDu}$ cell xenograft animal model. Taken together, these findings indicate that formononetin holds promise as a chemotherapeutic agent and may be of value in the treatment of human head and neck squamous cell carcinoma.

\section{Introduction}

Head and neck squamous cell carcinoma (HNSCC) is a type of cancer that develops from the mucosal lining of the upper aerodigestive tract, and is associated with a variety of pathophysiological risk factors, such as smoking, betel nut chewing, alcohol consumption and human papillomavirus infection. Approximately 600,000 new cases of HNSCC are currently diagnosed worldwide annually, making HNSCC the sixth most common type of cancer among human malignancies (1-3). Although clinical treatments for patients with HNSCC, such as surgery, radiation therapy, chemotherapy, targeted therapy and combination treatments, have advanced over the last two decades, the 5 year survival rate of patients diagnosed with HNSCC is estimated to be $65 \%$ (3). The clinical symptoms of HNSCC generally include a white or red patch on the gums or tongue and swelling of the jaw, accompanied by discomfort, abnormal bleeding and pain in the oral cavity, pharynx, larynx, salivary glands, paranasal sinuses and nasal cavity. 
The clinical treatments for HNSCC may cause side effects associated with functional changes in the ability to chew, swallow or talk, and may lead to multiple long-lasting physical and mental comorbidities (4). Recently, natural products used in traditional folk medicine have attracted attention as chemotherapeutic compounds in order to reduce the side effects of clinical HNSCC treatments (5).

As shown in Fig. 1, formononetin $\left[\mathrm{C}_{16} \mathrm{H}_{12} \mathrm{O}_{4}, \mathrm{CAS}\right.$ no: 485-72-3, synonym: 7-Hydroxy-3-(4'-methoxyphenyl)4H-benzopyran-4-one] is a phytoestrogen and natural isoflavone isolated from Pongamia pinnata (6), Astragalus membranaceus (7), Ononis angustissima (8) and Trifolium pratense (T. pratense) (9). Recent studies investigating the physiological roles of formononetin have reported a variety of biological effects, including antioxidant activity (10), estrogenic effects $(10)$, anti-inflammatory properties $(11,12)$, neuronal protection against hypoxia-induced cytotoxicity (13) and anti-neovascularization (14). Moreover, the anticancer properties of formononetin have been observed in several types of cancer cells, such as the human urinary bladder cancer cell line T24 (15), the human non-small-cell lung cancer cell lines A549 and NCI-H23 (16), the human prostate cancer cell lines PC-3 and DU145 (17), the human breast cancer cell line MDA-MB-231 (18), the human cervical cancer cell line HeLa (19), and the human colorectal carcinoma cell line HCT116 (20), and are mediated through anti-angiogenic effects, cell cycle arrest, inhibition of proliferation and induction of apoptosis.

Hence, the aim of the present study was to determine the chemotherapeutic effects of formononetin and its potential signaling pathways on HNSCC cells.

\section{Materials and methods}

Cell culture. L929 normal mouse fibroblasts and FaDu cells were obtained from the American Type Culture Collection (ATCC). According to the ATCC instructions, L929 cells were grown in Eagle's minimum essential medium (Thermo Fisher Scientific, Inc.) supplemented with $10 \%$ fetal bovine serum (FBS; Thermo Fisher Scientific, Inc.), and FaDu cells were grown in minimum essential medium (Thermo Fisher Scientific, Inc.) supplemented with $10 \%$ FBS; both were cultured in a humidified incubator at $37^{\circ} \mathrm{C}$ with $5 \% \mathrm{CO}_{2}$.

Cytotoxicity assessment. To determine the biological safety and cytotoxicity of formononetin (SC-202614; Santa Cruz Biotechnology Inc.), L929 and FaDu cells (1x10 5 cells $/ \mathrm{ml})$ were cultured in 96-well plates. Thereafter, the cells were treated with $0,5,10,25$ or $50 \mu \mathrm{M}$ formononetin for $24 \mathrm{~h}$ at $37^{\circ} \mathrm{C}$. Following incubation, the cells were incubated for a further $4 \mathrm{~h}$ in $20 \mu \mathrm{l}$ of $5 \mathrm{mg} / \mathrm{ml} \mathrm{MTT} \mathrm{solution} \mathrm{(Thermo}$ Fisher Scientific, Inc.). The supernatant was subsequently removed, and $200 \mu \mathrm{l} /$ well dimethyl sulfoxide (Sigma-Aldrich; Merck KGaA) was added to dissolve the MTT crystals. The optical density (OD) of each well was then measured at $570 \mathrm{~nm}$, using an Epoch microplate spectrophotometer (BioTek Instruments). The experiments were independently repeated three times. The mean $\mathrm{OD} \pm$ standard deviation for each group of replicates was calculated, and the entire procedure was then repeated three times.
Live/dead cell assay. The Live/Dead cell viability assay kit was obtained (Thermo Fisher Scientific, Inc.), which uses green calcein AM to stain the live cells (green fluorescence) and ethidium homodimer-1 to stain the dead cells (red fluorescence). $\mathrm{L} 929$ and FaDu cells $\left(1 \times 10^{5}\right.$ cells $\left./ \mathrm{ml}\right)$ were cultured in an 8-well chamber slide (Nunc ${ }^{\circledR}$ Lab-Tek $^{\circledR}$ Chamber Slide $^{\mathrm{TM}}$ system; Sigma-Aldrich; Merck KGaA), and allowed to attach to the bottom of the chamber slide overnight. Thereafter, cultured cells were treated with 0,10 or $25 \mu \mathrm{M}$ formononetin for $24 \mathrm{~h}$ at $37^{\circ} \mathrm{C}$ and stained using the Live/Dead cell viability assay kit, according to the manufacturer's instructions. Cells were imaged using a fluorescence microscope (Eclipse TE2000; Nikon Instruments).

Hematoxylin and eosin $(H \& E)$ staining. To investigate the morphological changes in FaDu cells induced by formononetin treatment, H\&E staining (3 min for hematoxylin and $30 \mathrm{sec}$ for eosin) was performed at room temperature. Briefly, FaDu cells ( $1 \times 10^{5}$ cells/ml) were cultured in an 8 -well chamber slide (Nunc ${ }^{\circledR}$ Lab-Tek $^{\circledR}$ Chamber Slide $^{\text {TM }}$ system; Sigma-Aldrich; Merck KGaA), and were allowed to adhere to the well overnight. Cultured cells were then treated with 0,10 or $25 \mu \mathrm{M}$ formononetin for $24 \mathrm{~h}$ at $37^{\circ} \mathrm{C}$. Thereafter, the cells were rinsed three times with phosphate-buffered saline (PBS) at $4^{\circ} \mathrm{C}$ and fixed with $4 \%$ paraformaldehyde for $30 \mathrm{~min}$ at $4^{\circ} \mathrm{C}$. H\&E staining was performed in order to observe morphological changes in the cells. The cells were observed and imaged using a Leica DM750 light microscope (Leica Microsystems).

Nuclear staining. To investigate nuclear condensation in $\mathrm{FaDu}$ cells treated with formononetin, DAPI staining was performed. Briefly, FaDu cells $\left(1 \times 10^{5}\right.$ cells $\left./ \mathrm{ml}\right)$ were cultured in an 8-well chamber slide (Nunc ${ }^{\circledR}$ Lab-Tek ${ }^{\circledR}$ Chamber Slide $^{\mathrm{TM}}$ system; Sigma-Aldrich; Merck KGaA), and allowed to adhere to the well overnight. Cultured cells were treated with 0,10 or $25 \mu \mathrm{M}$ formononetin for $24 \mathrm{~h}$ at $37^{\circ} \mathrm{C}$. Thereafter, the cells were rinsed three times with $\mathrm{PBS}$ at $4^{\circ} \mathrm{C}$ and stained with $1 \mathrm{mg} / \mathrm{ml}$ DAPI (Sigma-Aldrich; Merck KGaA) for $20 \mathrm{~min}$. Nuclear condensation was observed and imaged using a fluorescence microscope (Eclipse TE2000; Nikon Instruments).

Chromosomal DNA fragmentation assay. FaDu cells $\left(1 \times 10^{5}\right.$ cells $\left./ \mathrm{ml}\right)$ were cultured in 6 -well plates and allowed to adhere overnight. Cultured $\mathrm{FaDu}$ cells were treated with 0,10 or $25 \mu \mathrm{M}$ formononetin for $24 \mathrm{~h}$ at $37^{\circ} \mathrm{C}$, and rinsed three times with PBS at $4^{\circ} \mathrm{C}$. The cells were treated with $100 \mu \mathrm{l}$ cell lysis buffer [1\% NP-40, $20 \mathrm{mM}$ EDTA, $50 \mathrm{mM}$ Tris-HCl (pH 7.5 (all from Sigma-Aldrich; Merck KGaA)] and incubated at $4^{\circ} \mathrm{C}$ for $10 \mathrm{~min}$, then centrifuged at $12,000 \mathrm{x} \mathrm{g}$ at $4^{\circ} \mathrm{C}$ for $30 \mathrm{~min}$. RNase A (Bioneer) was added to the supernatant and incubated at $37^{\circ} \mathrm{C}$ for $1 \mathrm{~h}$. Subsequently, proteinase $\mathrm{K}$ (Bioneer) was added to the supernatant and incubated at $37^{\circ} \mathrm{C}$ for $8 \mathrm{~h}$. An equal volume of isopropanol (Sigma-Aldrich; Merck KGaA) was then added, and the lysates were incubated at $-80^{\circ} \mathrm{C}$ for $24 \mathrm{~h}$ to precipitate genomic DNA. Following centrifugation at $12,000 \mathrm{x} \mathrm{g}$ for $15 \mathrm{~min}$ at $4^{\circ} \mathrm{C}$, the supernatant was removed, allowed to dry naturally, and dissolved in Tris-EDTA buffer. Thereafter, the genomic DNA isolated from each sample was 


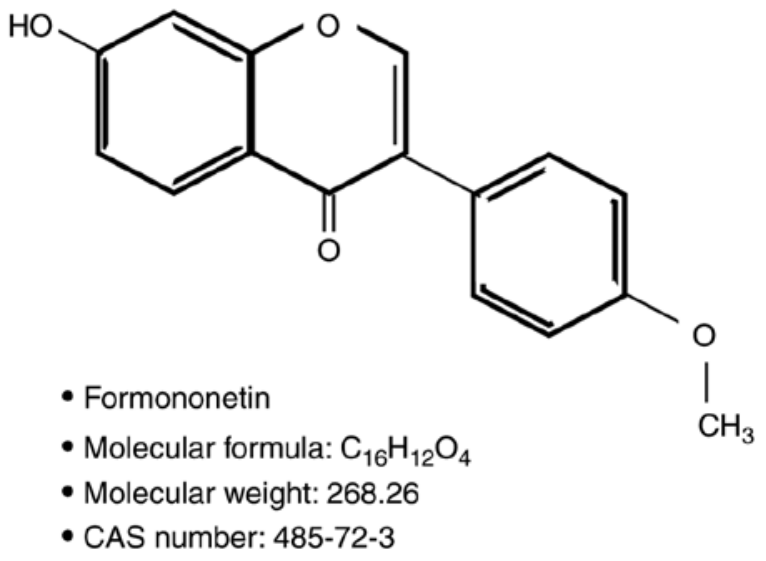

Figure 1. Chemical structure of formononetin.

electrophoresed on a $1.5 \%$ agarose gel (Bioneer). A gel imaging system (Transilluminator, Bioneer) was used for observation, and images were captured.

Caspase- 3 and -7 activity assay. The activity of caspase- 3 and -7 was assessed using the cell-permeable fluorogenic substrate PhiPhiLux- $\mathrm{G}_{1} \mathrm{D}_{2}$ (OncoImmunin Inc.) according to the manufacturer's instructions, and was imaged using fluorescence microscopy (Eclipse TE200; Nikon Instruments).

Fluorescence-activated cell sorting (FACS). FACS (BD Cell Quest ${ }^{\circledR}$ version 3.3) was performed using Annexin V-FITC Early Apoptosis Detection Kit (Cell Signaling Technology, Inc.) composed of Annexin V-FITC and propidium iodide (PI) to investigate changes in the apoptotic populations of $\mathrm{FaDu}$ cells treated with formononetin according to manufacturer's instructions. FaDu cells $\left(5 \times 10^{5}\right.$ cells $\left./ \mathrm{ml}\right)$ were cultured on a 6 -well plate for $24 \mathrm{~h}$, and then treated with 0,10 or $25 \mu \mathrm{M}$ formononetin for a further $24 \mathrm{~h}$. The cells were collected, washed with ice-cold PBS and resuspended in $1 \mathrm{X}$ binding buffer (BD Biosciences). Thereafter, $1 \mu \mathrm{l}$ Annexin V-FITC and 12.5 $\mu \mathrm{l}$ PI were added to $96 \mu \mathrm{l}$ cell suspension and incubated for $15 \mathrm{~min}$ at $37^{\circ} \mathrm{C}$. Changes in the apoptotic populations were analyzed using BD Cell Quest $^{\circledR}$ version 3.3 (Becton-Dickinson and Company).

Western blot analysis. FaDu cells $\left(5 \times 10^{5}\right.$ cells $\left./ \mathrm{ml}\right)$ were cultured on a 6-well plate and then treated with 0,10 or $25 \mu \mathrm{M}$ formononetin for a further $24 \mathrm{~h}$. Thereafter, cell lysates were prepared using a cell lysis buffer (Cell Signaling Technology, Inc.), according to the manufacturer's instructions. The protein concentration of the cell lysates was determined using a bicinchoninic acid protein assay (Thermo Fisher Scientific, Inc.). An equal amount $(30 \mu \mathrm{g})$ of each cell lysate was denatured at $100^{\circ} \mathrm{C}$ for $10 \mathrm{~min}$. Each cell lysate was electrophoresed on $10 \%$ sodium dodecyl sulfate polyacrylamide gel using mini-PROTEAN ${ }^{\circledR}$ Tetra Cell (Bio-Rad Laboratories, Inc.) attached with PowerPac $^{\text {TM }}$ HC Power Supply (Bio-Rad Laboratories, Inc.) and subsequently transferred to polyvinylidene fluoride (PVDF) membrane (Immobilon-P PVDF membrane, EMD Millipore) using mini Trans-Blot ${ }^{\circledR}$ Cell (Bio-Rad Laboratories, Inc.) attached with PowerPac ${ }^{\mathrm{TM}} \mathrm{HC}$ Power Supply (Bio-Rad Laboratories, Inc.) at $4^{\circ} \mathrm{C}$. Thereafter, the PVDF membranes were blocked using $5 \%(\mathrm{v} / \mathrm{v})$ bovine serum albumin (BSA;
Sigma-Aldrich; Merck KGaA) prepared in Tris-buffered saline with $0.05 \%$ Tween-20 (TBS-T; Santa Cruz Biotechnology Inc.) and then incubated with the primary antibodies at $4^{\circ} \mathrm{C}$ overnight. The following primary antibodies were purchased from Santa Cruz Biotechnology, Inc. and were diluted at 1:1,000 in TBS-T containing 5\% (v/v) BSA to perform western blotting: Antibodies against Fas Ligand (FasL; sc-33716), B-cell lymphoma-2 (Bcl-2; sc-56015), B-cell lymphoma-extra large (Bcl-xL; sc-136207) and Bax-like BH3 protein (Bid; sc-514622). In addition, the following primary antibodies were purchased from Cell Signaling Technology, Inc. and were diluted at 1:1,000 in TBS-T containing 5\% (v/v) BSA to perform western blotting: Antibodies against caspase-8 (cat. no. 9746), caspase-3 (cat. no. 9662), poly(ADP-ribose) polymerase (PARP; cat. no. 9532), Bcl-2-interacting killer (Bik; cat. no. 4592), Bcl-2-like protein 11 (Bim, cat. no. 2933), Bcl-2-antagonist of cell death (Bad; cat. no. 9292), Bcl-2-associated X protein (Bax; cat. no. 2772), caspase-9 (cat. no. 9508), $\beta$-actin (cat. no. 4970), phosphorylated extracellular signal-regulated kinase $1 / 2$ (p-ERK1/2; cat. no. 9101), total ERK1/2 (cat. no. 9102), p-p38 (cat. no. 4092), total p38 (cat. no. 9212), p-nuclear factor (NF)-кB (cat.no.3033), and total NF-кB (cat.no. 6956). Subsequently, they were incubated with horseradish peroxidase (HRP)-conjugated secondary antibodies (1:2,000; Santa Cruz Biotechnology, Inc.) for $2 \mathrm{~h}$ at room temperature. The immunoreactive bands were visualized using an ECL system (GE Healthcare), exposed on radiographic film or MicorChemi 4.2 (Dong-il SHIMADZU Corp.). Thereafter, the densitometric analysis of western blots was performed using ImageJ software $1.51 \mathrm{j} 8$ (W. Rasband, National Institutes of Health; available at http://rsb.info.nih. gov/ij/), an open source image processing program designed for scientific multidimensional images. The densitometric analysis of each image was repeated 3 times for statistical analysis.

In vivo study using an animal tumor model generated by a FaDu cell xenograft. All animal studies were performed under the protocol CIACUC2017-A0054 approved by the Institutional Animal Care and Use Committee of Chosun University (Gwangju, Korea). A total of $10 \mathrm{BALB} / \mathrm{c}$ male nude mice, aged 5 weeks and weighing $25.15 \pm 1.3 \mathrm{~g}$, were purchased from Damul Science. All animals were housed and were allowed to recover form shipping-associated stress for 1 week in a specific pathogen-free experimental animal housing center (temperature $25 \pm 10^{\circ} \mathrm{C}$, relative humidity $60 \pm 10 \%, 12 \mathrm{~h}$ light/dark cycle) with free access to autoclaved food and water. Following adaptation, the body weight of the animals was measured using a lab balance (Sartorius). Thereafter, FaDu cells $\left(1 \times 10^{7}\right.$ cells/100 $\mu 1$ PBS) were injected subcutaneously to generate a xenograft tumor model $(21,22)$. At 14 days after the injection, tumor formation was detected under the skin of mice that had received $\mathrm{FaDu}$ cell xenografts. Thereafter, the animals were divided into a xenograft positive control group $(n=5)$ and an experimental group $(n=5)$, in which the anticarcinogenic effect of formononetin was tested. A total of $10 \mathrm{mg} / \mathrm{kg}$ formononetin dissolved in 5\% ethanol and 5\% ethanol without formononetin were administered orally to the experimental and control groups, respectively, every other day for 21 days ( 3 weeks). The volume of the xenograft tumors was measured twice per week using the following formula (23): Volume $\left(\mathrm{mm}^{3}\right)$ of xenograft tumor $=1 / 2 \times$ length $(\mathrm{mm}) \times$ width $(\mathrm{mm})^{2}$ 

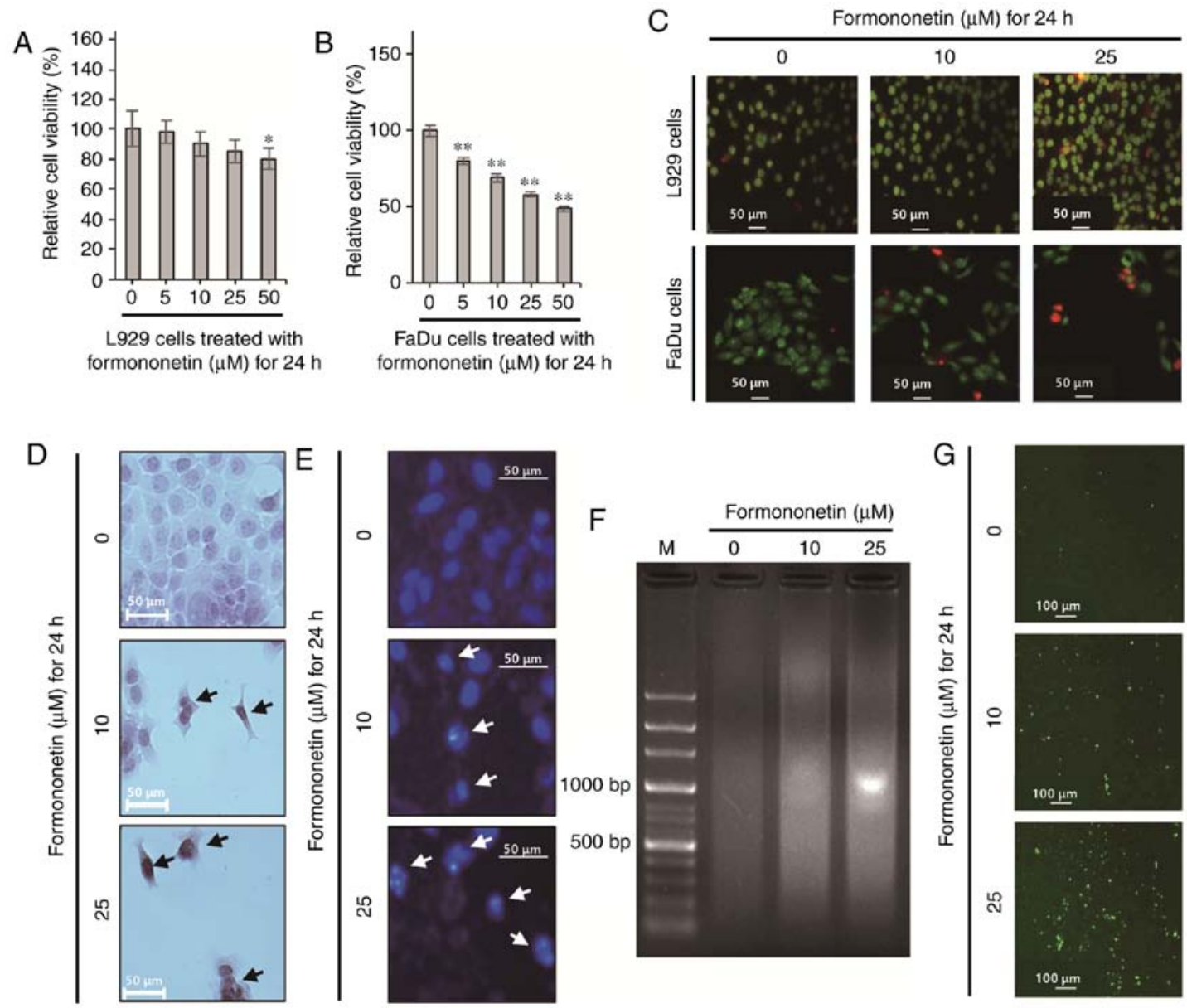

Figure 2. Formononetin induced FaDu cell death by inducing apoptosis. (A) Formononetin at 5-25 $\mu \mathrm{M}$ did not affect the viability of L929 mouse fibroblasts (B) The viability of FaDu cells decreased upon exposure to formononetin in a dose-dependent manner. (C) Formononetin induced the death of FaDu cells. Cells emitting green fluorescence are live cells stained by green calcein AM, whereas cells emitting red fluorescence are dead cells stained by ethidium homodimer-1. (D) Hematoxylin and eosin staining revealed that the number of FaDu cells with altered morphology (arrows; scale bar, $50 \mu \mathrm{m}$ ) was increased by formononetin. (E) DAPI staining revealed that the number of FaDu cells with nuclear condensation (arrows) was increased by formononetin. (F) DNA fragmentation was increased in FaDu cells treated with formononetin. (G) Formononetin increased the activity of caspase-3 and -7 in FaDu cells. ${ }^{*} \mathrm{P}<0.05$, ** $\mathrm{P}<0.01$.

Body weight was also recorded twice per week. At the end of the study, all animals were anesthetized with $1.5 \%$ isoflurane (Piramal Critical Care, Inc.), perfused with saline and fixed in $4 \%$ paraformaldehyde (Sigma-Aldrich; Merck KGaA). Finally, the tumors were dissected surgically and embedded in paraffin for immunohistochemical examination.

Immunohistochemistry. Dissected tumor tissues were fixed in $4 \%$ paraformaldehyde (Sigma-Aldrich; Merck KGaA) at $4^{\circ} \mathrm{C}$ for $72 \mathrm{~h}$, and were then processed with 70,95 and $100 \%$ ethanol (Sigma-Aldrich; Merck KGaA), xylene (Sigma-Aldrich; Merck KGaA), and paraffin (Paraplast plus ${ }^{\circledR}$; Sigma-Aldrich; Merck KGaA). Thereafter, tumor tissues were embedded in paraffin, prepared and cut into $8 \mu \mathrm{m}$ sections using a Leica ${ }^{\circledR}$ RM2235 manual rotary microtome (Leica Biosystems Inc.), and mounted on glass slides. The sections were deparaffinized using xylene, rehydrated with two washes each of 100 and $95 \%$ ethanol and then rinsed with tap water. The sections were incubated at $4^{\circ} \mathrm{C}$ with caspase- 3 antibody overnight [cat. no. 9662 , Cell Signaling Technology, Inc.; dilution, 1:1,000 in $5 \mathrm{ml}$ PBS-T (PBS with $0.05 \%$ Tween-20) containing $250 \mu 1$ normal goat serum (cat. no. 5425; Cell Signaling Technology, Inc.)]. Thereafter, immunohistochemistry was performed using the
Vectastain ${ }^{\circledR} \mathrm{ABC}$ kit (Vector Laboratories, Inc.) according to the manufacturer's instructions. The sections were subsequently transferred to mounting reagent, and examined under a fluorescence microscope (Eclipse TE200; Nikon Instruments).

Statistical analysis. The experimental data are presented as the mean \pm standard deviation and were compared using analysis of variance, followed by post-hoc multiple comparison (Tukey's test) using SPSS software version 25 (IBM Corp.) The Student's t-test was performed to analyze the significance of differences between animal groups. $\mathrm{P}<0.05$ was considered to indicate statistically significant differences. All the data, except the animal study, were obtained from three independent experiments.

\section{Results}

Formononetin decreases the viability of FaDu cells without affecting the viability of L929 mouse fibroblasts. L929 mouse fibroblasts, which were used as normal cells, were cultured in 5-50 $\mu \mathrm{M}$ formononetin for $24 \mathrm{~h}$. The MTT assay was then performed to evaluate the cytotoxicity of formononetin. As shown in Fig. 2A, treatment with 5-25 $\mu \mathrm{M}$ formononetin did not significantly decrease the viability of L929 mouse fibroblasts; 

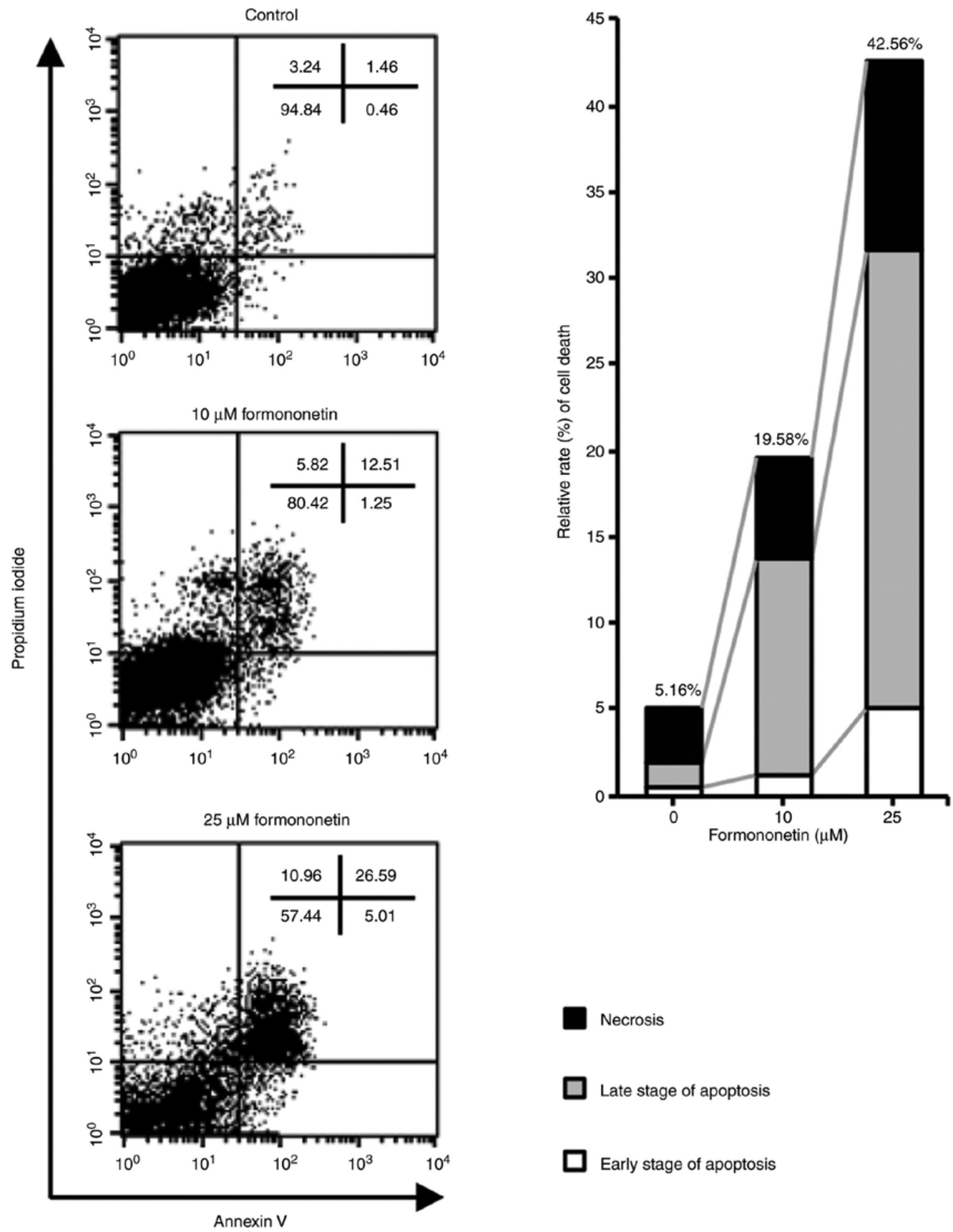

Figure 3. The apoptotic cell population increased in FaDu cells treated with formononetin. FaDu cells were treated with 10 and $25 \mu \mathrm{M}$ formononetin for $24 \mathrm{~h}$. Thereafter, FACS analysis using propidium iodide and Annexin V staining was performed to measure the apoptotic population.

however, treatment with $50 \mu \mathrm{M}$ formononetin decreased the viability of L929 mouse fibroblasts to $82 \pm 3 \%$ compared with the control $(\mathrm{P}<0.05)$. The relative cell viability was found to be $79 \pm 2,65 \pm 3,58 \pm 3$ and $46 \pm 2 \%$ in FaDu cells treated with $5,10,25$ and $50 \mu \mathrm{M}$ formononetin, respectively (all $\mathrm{P}<0.01$; Fig. 2B). These data demonstrate that formononetin induces $\mathrm{FaDu}$ cell death in a dose-dependent manner, and the $\mathrm{IC}_{50}$ value of formononetin was $\sim 39.7 \mu \mathrm{M}$ in FaDu cells. To confirm the viability of L929 mouse fibroblasts and FaDu cells treated with 10 or $25 \mu \mathrm{M}$ formononetin for $24 \mathrm{~h}$, a Live/Dead cell assay was performed, using green calcein $\mathrm{AM}$ and ethidium homodimer-1 to stain live and dead cells, respectively. As shown in Fig. 2C, almost all L929 cells treated with formononetin emitted green fluorescence following staining with green calcein AM, which stains live cells. However, FaDu cells exposed to formononetin emitted red fluorescence in a dose-dependent manner following staining with ethidium homodimer-1, which stains dead cells. Taken together, these findings indicate that formononetin at 10 and $25 \mu \mathrm{M}$ induces FaDu cell death without affecting the viability of normal fibroblasts (Fig. 2A-C). Hence, 10 and $25 \mu \mathrm{M}$ formononetin was used to treat FaDu cells in the present study. 
A Formononetin $(\mu \mathrm{M})$ for $24 \mathrm{~h}$

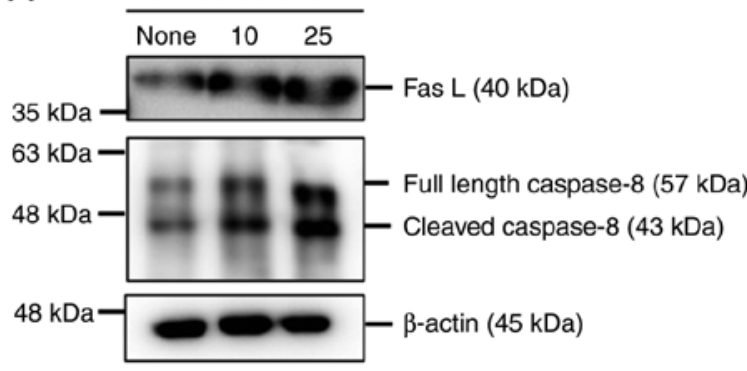

C

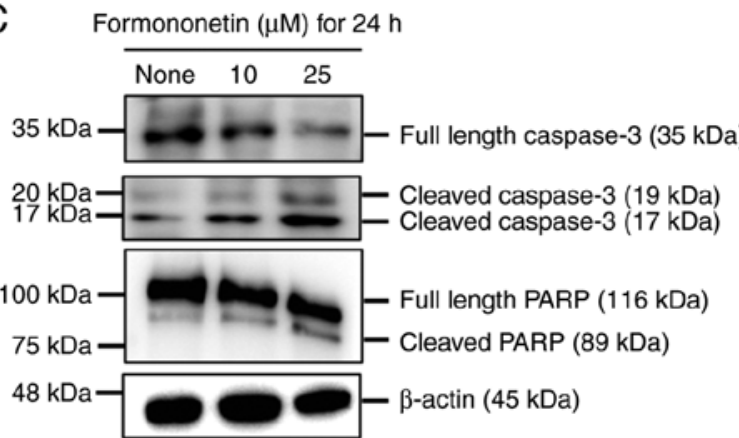

B

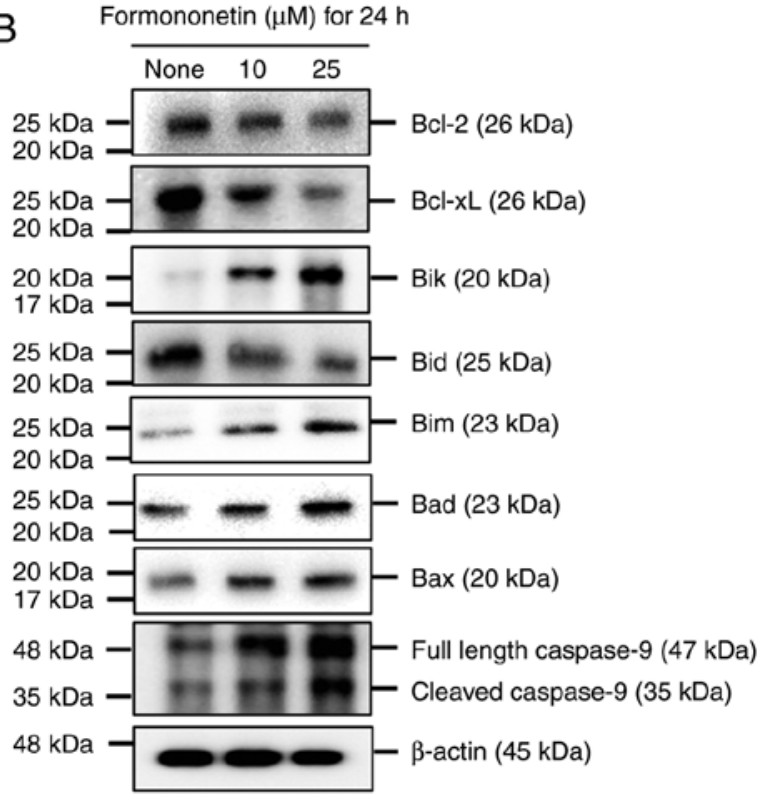

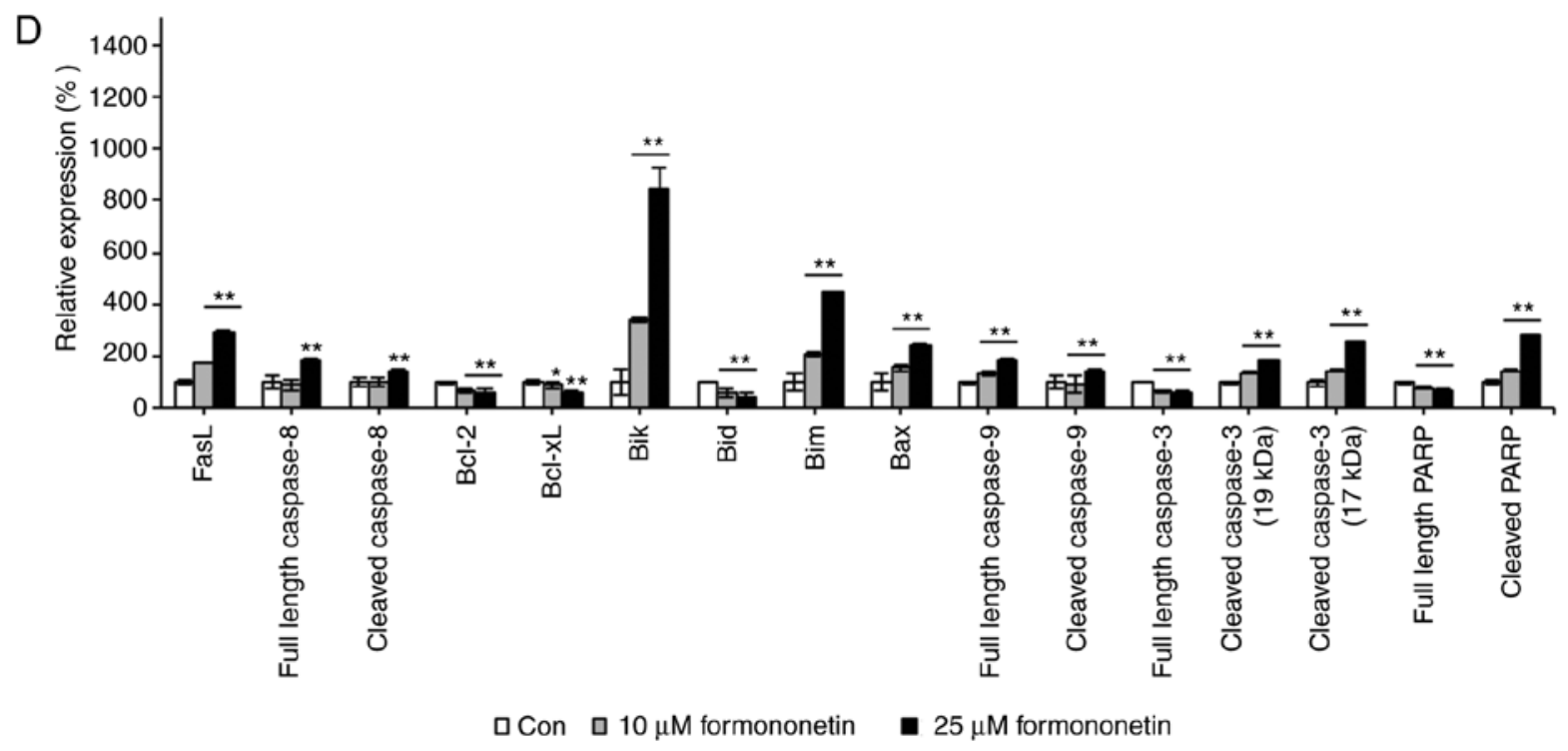

Figure 4. Formononetin-induced FaDu cell death was coordinated by both the death receptor-mediated extrinsic and mitochondria-dependent intrinsic apoptosis pathways. FaDu cells were treated with 10 and $25 \mu \mathrm{M}$ formononetin for $24 \mathrm{~h}$. Following protein extraction and quantification, western blotting was performed using antibodies against apoptosis-associated markers. (A) Formononetin induced the cleavage of caspase-8 through the upregulation of FasL expression in FaDu cells. (B) Formononetin induced the cleavage of caspase-9 though the upregulation of the expression of pro-apoptotic factors, such as Bik, Bim, and Bax, cleavage of Bid, and downregulation of the expression of anti-apoptotic factors, such as Bcl-2 and Bcl-xL, in FaDu cells. (C) The activation of caspase-3 and its downstream target substrate PARP by activated caspsase- 8 and caspase-9 increased in formononetin-treated FaDu cells. (D) Expression of target proteins graphically presented by densitometric analysis using ImageJ software based on the western blotting results and expressed as the mean \pm standard deviation ( $\mathrm{P}<0.05$ and $^{* *} \mathrm{P}<0.01$ compared with the control).

Formononetin induces apoptotic death in FaDu cells. To elucidate the cellular mechanism through which formononetin induces FaDu cell death, the formation of apoptotic bodies and morphological changes in $\mathrm{FaDu}$ cells treated with formononetin were observed following H\&E staining. As shown in Fig. 2D, the number of FaDu cells was progressively reduced with increasing concentrations of formononetin. Furthermore, morphological changes similar to apoptotic body formation, including outward membrane bulges and shrinkage, were observed in FaDu cells treated with formononetin. Therefore, to determine whether formononetin-induced FaDu cell death is due to apoptosis, DAPI staining was performed to detect nuclear condensation, a typical feature of apoptosis. As shown in Fig. 2E, the number of FaDu cells with condensed nuclei increased upon exposure to formononetin in a dose-dependent manner. Moreover, genomic DNA fragmentation, another characteristic of apoptosis, was increased in FaDu cells treated with formononetin, as shown in Fig. 2F (arrows). As shown in Fig. 2G, the number of FaDu cells emitting green fluorescence due to the cleavage of the cell permeable fluorogenic 


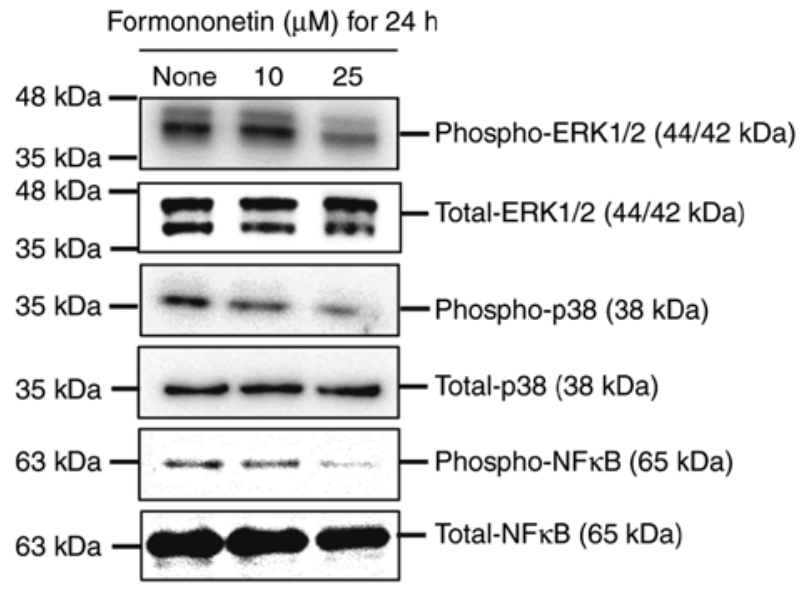

Figure 5. Formononetin-induced apoptosis was mediated by the suppression of mitogen-activated protein kinase and nuclear factor (NF)- $\mathrm{kB}$ phosphorylation in $\mathrm{FaDu}$ cells. FaDu cells were treated with 10 and $25 \mu \mathrm{M}$ formononetin for $24 \mathrm{~h}$. Following protein extraction and quantification, western blotting was performed using antibodies against p-ERK1/2, total ERK1/2, p-p38, total $\mathrm{p} 38, \mathrm{p}-\mathrm{NF}-\mathrm{\kappa B}$ and total NF- $\mathrm{kB}$.

substrate PhiPhiLux- $\mathrm{G}_{1} \mathrm{D}_{2}$ by cleaved caspase- 3 increased significantly in a dose dependent manner in the presence of formononetin.

FACS analysis using Annexin V and PI staining was subsequently performed to confirm formononetin-induced apoptosis of FaDu cells. As shown in Fig. 3, the relative rates of cell death were 19.58 and $42.56 \%$ in FaDu cells treated with 10 and $25 \mu \mathrm{M}$ formononetin for $24 \mathrm{~h}$, respectively. Furthermore, the early- and late-stage apoptotic cell populations were 13.76 and $31.6 \%$ in FaDu cells treated with 10 and $25 \mu \mathrm{M}$ formononetin for $24 \mathrm{~h}$, respectively. Therefore, the FACS analysis indicated that formononetin induces cell death by increasing the population of apoptotic $\mathrm{FaDu}$ cells. These data strongly suggest that formononetin induces apoptotic cell death in FaDu cells in a dose-dependent manner.

Formononetin-induced FaDu cell death involves death receptor-mediated extrinsic and mitochondria-dependent intrinsic apoptosis. To investigate formononetin-induced FaDu cell death, western blot analyses were performed using antibodies associated with death receptor-mediated extrinsic and mitochondria dependent-intrinsic apoptosis, as shown in Fig. 4. The level of FasL significantly increased in FaDu cells treated with formononetin, as shown in Fig. 4A. Additionally, cleaved caspase- 8 levels increased in a dose-dependent manner in FaDu cells treated with 10 and $25 \mu \mathrm{M}$ formononetin. These data indicate that formononetin-induced apoptosis is coordinated by an extrinsic death receptor-mediated apoptotic pathway through FasL and caspase-8 in FaDu cells.

Furthermore, the expression of anti-apoptotic factors, such as Bcl-2 and Bcl-xL, was found to be decreased in $\mathrm{FaDu}$ cells upon treatment with 10 and $25 \mu \mathrm{M}$ formononetin in a dose-dependent manner. In addition, the expression of Bid, which is a precursor of truncated Bid (tBid) acting as a pro-apoptotic factor, decreased dose-dependently by formononetin in FaDu cells. Conversely, the expression of Bik, Bim, Bax and cleaved caspase-9, which are pro-apoptotic factors associated with the mitochondria-dependent intrinsic apoptosis pathway, increased in $\mathrm{FaDu}$ cells treated with formononetin, as shown in Fig. 4B. These data indicate that formononetin-induced $\mathrm{FaDu}$ cell apoptosis is mediated by the mitochondria-dependent intrinsic apoptosis pathway, involving downregulation of anti-apoptotic factor expression, upregulation of pro-apoptotic factor expression, and the activation of caspase-9. As shown in Fig. 4C, the levels of cleaved caspase-3 increased in FaDu cells treated with 10 and $25 \mu \mathrm{M}$ formononetin due to the cleavage of pro-caspase-3, a downstream substrate of cleaved caspase- 8 and cleaved caspase- 9 . Additionally, the levels of cleaved PARP increased due to the cleavage of pro-PARP, a downstream substrate of cleaved caspase-3. These findings indicate that formononetin-induced FaDu cell death is coordinated by death receptor-mediated extrinsic and mitochondria-dependent intrinsic apoptosis through activation of the caspase cascade in FaDu cells.

The chemotherapeutic effects of formononetin are mediated by the suppression of mitogen-activated protein kinases (MAPKs) in FaDu cells. To investigate the signal transduction pathways associated with formononetin-induced apoptosis in FaDu cells, western blotting was performed, using antibodies specific to MAPKs, such as ERK1/2 and p38, and NF- $\kappa \mathrm{B}$, as shown in Fig. 5. Formononetin was found to suppress the phosphorylation of ERK1/2, p38 and NF- $\mathrm{kB}$ in FaDu cells in a dose-dependent manner. These findings indicate that formononetin-induced $\mathrm{FaDu}$ cell apoptosis is mediated by the suppression of the ERK1/2, p38 and NF- $\mathrm{KB}$ phosphorylation.

Formononetin suppresses tumor formation in a FaDu cell xenograft animal model. To assess the effects of formononetin on FaDu tumor growth in vivo, FaDu cells were xenografted into experimental mice and the resulting tumor sizes and body weights were measured weekly for up to 3 weeks. As shown in Fig. 6A, the body weight of the xenograft group administered $10 \mathrm{mg} / \mathrm{kg}$ formononetin was $27.05 \pm 1.35 \mathrm{~g}$, which was $\sim 9.5 \%$ higher compared with that of the control group $(24.7 \pm 1.98 \mathrm{~g})$ at 21 days. There was no obvious loss of body weight in xenograft animals over the 3 weeks, indicating that formononetin was well-tolerated. Tumor volume and weight were significantly lower in mice receiving formononetin compared with those in the control group, as shown in Fig. 6B and C. Furthermore, immunohistochemical analysis of the tumors demonstrated that the expression of cleaved caspase- 3 was markedly increased in formononetin-treated tumors compared with the controls (Fig. 6D). Taken together, these data indicate that formononetin suppressed tumor formation through apoptotic cell death in a $\mathrm{FaDu}$ xenograft animal model.

\section{Discussion}

HNSCC forms on the mucosal surfaces of the upper aerodigestive tract, including the oral cavity, pharynx, larynx and paranasal sinuses, and is generally treated by surgery, alone or in combination with radiotherapy and chemotherapy, depending on tumor stage and location $(21,22)$. However, these HNSCC treatments frequently compromise the quality of life of the patients due to their side effects, such as masticatory dysfunction and psychological problems caused by altered orofacial appearance (22). Therefore, the develop- 

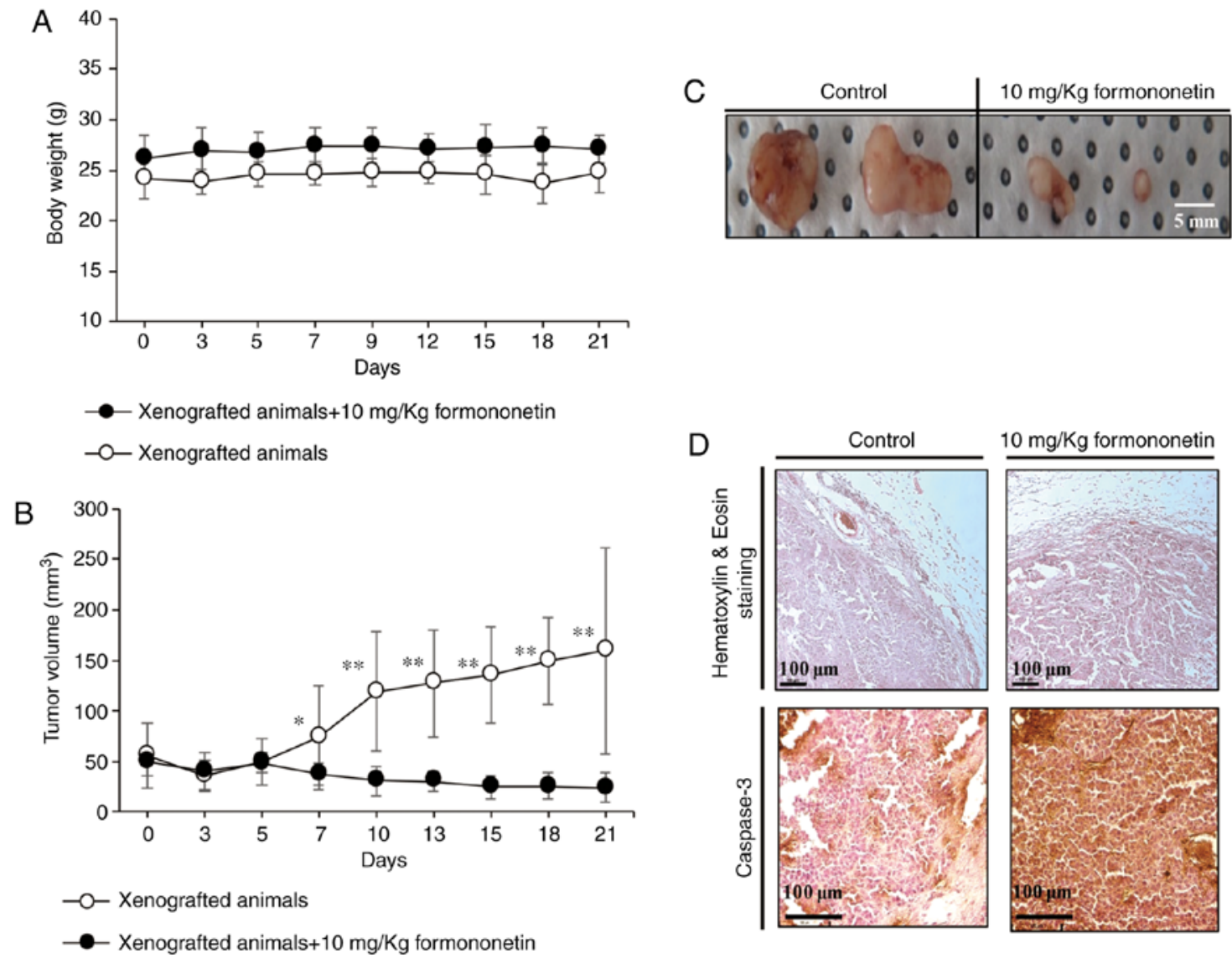

Figure 6. Formononetin inhibited tumor growth in FaDu HNSCC xenografts. (A) Oral administration of $10 \mathrm{mg} / \mathrm{kg}$ formononetin did not affect the body weight of FaDu HNSCC xenograft animals. (B) Oral administration of formononetin significantly inhibited the tumor growth in a FaDu HNSCC xenograft animal model. Formononetin $(10 \mathrm{mg} / \mathrm{kg})$ and vehicle were orally administered to the experimental and control groups, respectively, every other day for 3 consecutive weeks. Tumor size was measured using a caliper prior to the oral administration of formononetin. (C) Oral administration of $10 \mathrm{mg} / \mathrm{kg}$ formononetin effectively suppressed tumor growth in a FaDu xenograft animal model. Representative tumor masses from mice with FaDu xenografts are shown. (D) Caspase-3 was upregulated in tumor tissues collected from FaDu cell xenografted animals receiving $10 \mathrm{mg} / \mathrm{kg}$ formononetin. Upper panels, hematoxylin and eosin staining; lower panels, caspase-3 immunohistochemistry. HNSCC, head and neck squamous cell carcinoma.

ment of biologically safe chemotherapeutic agents, which display outstanding anticancer efficacy by focusing on cancer cell-specific apoptosis and reducing side effects, is of great importance. Recent studies associated with the development of chemotherapeutic agents have focused on the anticancer properties of natural compounds isolated from herbal plants used in folk medicine or biologically proven natural materials.

Phytoestrogens, which are natural compounds similar to $17 \beta$-estradiol, are present in various edible fruits, vegetables, and some herbal plants $(23,24)$. Phytoestrogens have been found to mediate physiological and pathological responses associated with reproduction, bone remodeling, cardiovascular function, immune system activity, and several other metabolic diseases, through interaction with the estrogen receptor $(23,24)$. In addition, it was recently reported that phytoestrogens play a role in the prevention and treatment of various cancers, including liver, lung, colon, breast, prostate and oral cancers (25). In our previous study, we reported that biochanin-A, a phytoestrogen derived from T.pretense (known as red clover in traditional medicine) induced the apoptosis of FaDu cells via the death receptor-dependent extrinsic and mitochondria dependent-intrinsic apoptosis pathways (26). We herein demonstrated that formononetin, a phytoestrogen isolated from herbal plants, induced FaDu cell death via death receptor-mediated extrinsic and mitochondria-dependent intrinsic apoptosis.

In the present study, formononetin did not affect the viability of L929 fibroblasts used as normal cells. Huh et al reported that the proliferation of human umbilical vein endothelial cells was accelerated when treated with $1-100 \mu \mathrm{M}$ formononetin (27); however, this did not affect the viability of normal subchondral osteoblasts (28). Hence, these results indicate that the 5-25 $\mu \mathrm{M}$ formononetin dose range used in the present study may be biologically safe for normal cells, whereas the viability of $\mathrm{FaDu}$ cells treated with 5-50 $\mu \mathrm{M}$ formononetin decreased in a dose-dependent manner. In agreement with our results, formononetin was also found to decrease the viability of human osteosarcoma U2OS cells (29), human non-small-cell lung cancer A549 and NCL-H23 cells (16), human prostate cancer DU-145 cells (30), human cervical cancer HeLa cells (19), and human breast cancer MCF-7 cells (31), in a time- and dose-dependent manner. Although these studies have consistently demonstrated that formononetin is toxic to various cancer cells, to the best of our knowledge, the present study was the first to identify that formononetin induces cell death in human HNSCC. Furthermore, the present study determined the concentration of formononetin that increased FaDu cell death without affecting normal fibroblasts. 
Apoptosis, also referred to as programmed cell death, is mediated by biochemical alterations that include cell shrinkage (32), nuclear condensation (33), chromosomal DNA fragmentation (34), and activation of the caspase cascade (35). The results of the present study indicated that formononetin-induced $\mathrm{FaDu}$ cell death was mediated by apoptosis. Moreover,FACS analysis with Annexin V and PI staining revealed that cell populations in both the early and late stages of apoptosis gradually increased. These data strongly indicate that formononetin induces apoptosis in FaDu cells.

Targeting the regulation of cellular mechanisms to accelerate cell death is a highly effective strategy for cancer therapy. Apoptosis is a particularly important mechanism associated with the elimination of unwanted cells during development to maintain homeostasis in long-lived mammals (36). Therefore, a number of recent studies associated with the development of chemotherapeutic agents have focused on inducing cancer cell-specific apoptosis by modulating apoptotic signaling pathways.

Apoptosis is generally activated by either the death receptormediated extrinsic or mitochondria dependent-intrinsic pathways, and is highly regulated by the activation (cleavage) of caspases (cysteine aspartyl-specific proteases) to induce cell death (36). The death receptor-mediated extrinsic apoptosis pathway is triggered by the recruitment of adaptor proteins, such as Fas-associated death domain (FADD) and tumor necrosis factor (TNF) receptor-associated death domain (TRADD), through the binding of death ligands [e.g. FasL, TNF-related apoptosis-inducing ligand (TRAIL) and TNF] to TNF family death receptors (37-39). Subsequently, adaptor proteins induce the activation of caspase- 8 through the cleavage of pro-caspase- 8 , then activated caspase- 8 induces the activation of executioner caspase-3, which leads to cell death (38). In the present study, formononetin increased the expression of FasL and the activation of caspase- 8 in FaDu cells. Consequently, the activation of caspase- 3 , a downstream target molecule of caspase- 8 and caspase- 9 , and its downstream pro-apoptotic substrate PARP, was also increased in $\mathrm{FaDu}$ cells treated with formononetin. These results indicate that formononetin-induced apoptosis is coordinated by the death receptor-mediated extrinsic apoptosis pathway, through the upregulated expression of the death ligand FasL in FaDu cells.

Generally, the mitochondria-dependent intrinsic apoptosis pathway is initiated by the cleavage of Bid to tBid in response to apoptotic stress, such as DNA injury, upregulation of oncogenes, growth factor deprivation, increased $\mathrm{Ca}^{2+}$ levels, DNA-damaging molecules, oxidants and microtubule-targeting drugs (40). In addition, the activation of caspase- 8 , which is involved in the death receptor-mediated extrinsic apoptosis pathway, can initiate the mitochondria-dependent intrinsic apoptosis pathway by cleaving Bid to tBid (41). The oligomerization of activated Bax and Bcl-2-antagonist/killer (Bak) lead to the release of intermembrane cytochrome $c$ by inducing mitochondrial outer membrane permeabilization (42). Although anti-apoptotic factors, such as Bcl-2 and Bcl-xL, regulate the oligomerization of activated Bax and Bak, the anti-apoptotic activity of these factors is regulated by pro-apoptotic factors, such as Bik, Bim and Bad $(43,44)$. In the present study, the activation of caspase- 8 decreased Bid levels by cleaving Bid to $\mathrm{tBid}$ in FaDu cells treated with formononetin. In addition, formononetin reduced anti-apoptotic activity by downregulating the expression of anti-apoptotic factors, such as Bcl-2 and $\mathrm{Bcl}-\mathrm{xL}$, in FaDu cells. Moreover, formononetin increased the expression of mitochondria-dependent pro-apoptotic factors, such as Bik and Bim. Alterations in the levels of these anti- and pro-apoptotic factors associated with the mitochondria-dependent apoptosis pathway subsequently induced the activation cascade of caspase-9, caspase-3 and PARP in FaDu cells treated with formononetin. Taken together, these findings indicate that formononetin-induced apoptosis is mediated by mitochondria-dependent intrinsic apoptotic pathways through the activation of caspase- 8 , which is triggered by upregulated FasL expression in FaDu cells. In agreement with the findings of the present study, formononetin has also been found to induce mitochondria-dependent apoptotic pathways by downregulating Bcl-2 and upregulating Bax in U2OS human osteosarcoma cells, A549 human non-small-cell lung cancer cells, and DU-145 and PC-3 human prostate cancer cells $(16,29,30,45)$.

Generally, MAPKs are closely associated with tumor cell proliferation, differentiation, apoptosis, angiogenesis, invasion and metastasis (46). In the present study, the phosphorylation of ERK1/2 and p38 was suppressed in a dose-dependent manner in $\mathrm{FaDu}$ cells treated with formononetin. Recent studies have reported that the MAPK signaling pathway may directly or indirectly suppress the activation of caspase- 3 and caspase- 9 by inhibiting the release of cytochrome $c$ from mitochondria (46-49). NF- $\mathrm{KB}$ is a cell signaling molecule that regulates the expression of several genes associated with immune responses, cell adhesion, cell differentiation, cell proliferation, angiogenesis and apoptosis (50). However, NF- $\mathrm{KB}$ activation is suppressed

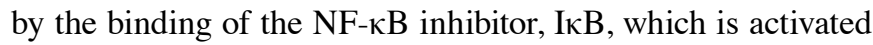
by Akt phosphorylation (51). Recently, Alam et al reported that the expression of the anti-apoptotic factor Bcl-2 was positively correlated with NF- $\mathrm{\kappa B}$ activity and closely associated with the progression and resistance to treatment of oral squamous carcinoma (52). Therefore, as MAPK and NF- $\mathrm{kB}$ signaling is frequently activated in cancer cells, the inactivation of this signaling pathway may contribute to the anticarcinogenic effects.

In the present study, orally administered formononetin effectively suppressed tumor growth compared with the control group. Consistently with our results, formononetin-induced antitumor effects, including apoptosis and the suppression of tumor growth, have been reported in several types of cancer cells, such as human breast cancer (53), osteosarcoma (29), cervical cancer (19) and colon cancer (20) cell lines. Moreover, Tyagi et al reported that the oral administration of resveratrol, a representative phytoestrogen derived from red wine, induced the apoptosis of FaDu cells through the upregulation of cleaved caspase-3 in xenograft animal models (54). Similarly, the histological results of the present study demonstrated that the expression of cleaved caspase-3 was significantly upregulated in the tumor tissues dissected from xenograft animals receiving formononetin compared with those in the control group. These data indicate that formononetin induces the expression of cleaved caspase-3 through both the death receptor-mediated extrinsic and mitochondria-dependent intrinsic apoptotic pathways.

Recent studies reported that formononetin exerts additional chemotherapeutic effects, such as inhibition of cancer cell proliferation (15) and angiogenesis (53), and suppression of invasion and migration in various types of tumors (18). However, 
the present study only focused on formononetin-induced apoptotic cell death and its cellular signaling mechanism. Other formononetin-induced antitumor effects, including the inhibition of proliferation, angiogenesis, invasion and migration, will be investigated in further in vitro and in vivo studies.

In conclusion, formononetin, a phytoestrogen derived from $T$. pratense, effectively promotes cell death via death receptor-mediated extrinsic and mitochondria-dependent intrinsic apoptosis in FaDu cells. These findings suggest that formononetin may be a promising chemotherapeutic candidate for the treatment of HNSCC.

\section{Acknowledgements}

Not applicable.

\section{Funding}

The present study was supported by a research fund from Chosun University Dental Hospital, 2019.

\section{Availability of data and materials}

The analyzed datasets generated during the present study are available from the corresponding author on reasonable request.

\section{Authors' contributions}

JSO, THK, JHP, HL, IAC and JSK substantially contributed to the conception and design of the manuscript, drafted the article and revised it for important intellectual content. JSO, JSY, GJL, YSS, DKK, CSK, SKY, HJK, SGK and JSK acquired, analyzed and interpreted the data. All authors have read and approved the final version of the manuscript and agree to be accountable for all aspects of the research, ensuring that the accuracy or integrity of any part of the work are appropriately investigated and resolved.

\section{Ethics approval and consent to participate}

All animal studies were performed according to the protocol (CIACUC2017-A0054) approved by the Institutional Animal Care and Use Committee of Chosun University.

\section{Patient consent for publication}

Not applicable.

\section{Competing interests}

The authors declare that they have no competing interests.

\section{References}

1. Qi X, Jia B, Zhao X and Yu D: Advances in T-cell checkpoint immunotherapy for head and neck squamous cell carcinoma. Onco Targets Ther 10: 5745-5754, 2017.

2. Bonomo P, Loi M, Desideri I, Olmetto E, Delli Paoli C, Terziani F, Greto D, Mangoni M, Scoccianti S, Simontacchi G, et al: Incidence of skin toxicity in squamous cell carcinoma of the head and neck treated with radiotherapy and cetuximab: A systematic review. Crit Rev Oncol Hematol 120: 98-110, 2017.
3. Belcher R, Hayes K, Fedewa S and Chen AY: Current treatment of head and neck squamous cell cancer. J Surg Oncol 110: 551-574, 2014.

4. Kundu SK and Nestor M: Targeted therapy in head and neck cancer. Tumour Biol 33: 707-721, 2012.

5. Shrotriya S, Agarwal R and Sclafani RA: A perspective on chemoprevention by resveratrol in head and neck squamous cell carcinoma. Adv Exp Med Biol 815: 333-348, 2015.

6. Li J, Jiang Z, Li X, Hou Y, Liu F, Li N, Liu X and Yang L: Natural therapeutic agents for neurodegenerative diseases from a traditional herbal medicine Pongamia pinnata (L.) Pierre. Bioorg Med Chem Lett 25: 53-58, 2015.

7. Li W, Sun YN, Yan XT, Yang SY, Kim S, Lee YM, Koh YS and Kim YH: Flavonoids from Astragalus membranaceus and their inhibitory effects on LPS-stimulated pro-inflammatory cytokine production in bone marrow-derived dendritic cells. Arch Pharm Res 37: 186-192, 2014.

8. Ghribi L, Waffo-Teguo P, Cluzet S, Marchal A, Marques J, Mérillon JM and Ben Jannet H: Isolation and structure elucidation of bioactive compounds from the roots of the Tunisian Ononis angustissima L. Bioorg Med Chem Lett 25: 3825-3830, 2015.

9. Tava A, Pecio L, Stochmal A and Pecetti L: Clovamide and flavonoids from leaves of Trifolium pratense and T. pratense subsp. Nivale grown in Italy. Nat Prod Commun 10: 933-936, 2015.

10. Mu H, Bai YH, Wang ST, Zhu ZM and Zhang YW: Research on antioxidant effects and estrogenic effect of formononetin from Trifolium pratense (red clover). Phytomedicine 16: 314-319, 2009.

11. Xu N and An J: Formononetin ameliorates mast cell-mediated allergic inflammation via inhibition of histamine release and production of pro-inflammatory cytokines. Exp Ther Med 14: 6201-6206, 2017.

12. Ma Z, Ji W, Fu Q and Ma S: Formononetin inhibited the inflammation of LPS-induced acute lung injury in mice associated with induction of PPAR gamma expression. Inflammation 36: 1560-1566, 2013.

13. Sun M, Zhou T, Zhou L, Chen Q, Yu Y, Yang H, Zhong K, Zhang X, Xu F, Cai S, et al: Formononetin protects neurons against hypoxia-induced cytotoxicity through upregulation of ADAM10 and sA $\beta P P \alpha$. J Alzheimers Dis 28: 795-808, 2012.

14. Wu J,Ke X, Ma N, Wang W, Fu W, Zhang H,Zhao M, Gao X, Hao X and Zhang Z: Formononetin, an active compound of Astragalus membranaceus (Fisch) Bunge, inhibits hypoxia-induced retinal neovascularization via the HIF-1 $\alpha /$ VEGF signaling pathway.. Drug Des Devel Ther 10: 3071-3081, 2016.

15. Wu Y, Zhang X, Li Z, Yan H, Qin J and Li T: Formononetin inhibits human bladder cancer cell proliferation and invasiveness via regulation of MiR-21 and PTEN. Food Funct 8: 1061-1066, 2017.

16. Yang Y, Zhao Y, Ai X, Cheng B and Lu S: Formononetin suppresses the proliferation of human non-small cell lung cancer through induction of cell cycle arrest and apoptosis. Int $\mathrm{J} \mathrm{Clin}$ Exp Pathol 7: 8453-8461, 2014.

17. Li T, Zhao X, Mo Z, Huang W, Yan H, Ling Z and Ye Y: Formononetin promotes cell cycle arrest via downregulation of Akt/Cyclin D1/CDK4 in human prostate cancer cells. Cell Physiol Biochem 34: 1351-1358, 2014.

18. Zhou R, Xu L, Ye M, Liao M, Du H and Chen H: Formononetin inhibits migration and invasion of MDA-MB-231 and 4T1 breast cancer cells by suppressing MMP-2 and MMP-9 through PI3K/AKT signaling pathways. Horm Metab Res 46: 753-760, 2014.

19. Jin YM, Xu TM, Zhao YH, Wang YC and Cui MH: In vitro and in vivo anti-cancer activity of formononetin on human cervical cancer cell line HeLa. Tumour Biol 35: 2279-2284, 2014.

20. Auyeung KK, Law PC and Ko JK: Novel anti-angiogenic effects of formononetin in human colon cancer cells and tumor xenograft. Oncol Rep 28: 2188-2194, 2012.

21. Lydiatt WM, Patel SG, O'Sullivan B, Brandwein MS, Ridge JA, Migliacci JC, Loomis AM and Shah JP: Head and Neck cancers-major changes in the American Joint Committee on cancer eighth edition cancer staging manual. CA Cancer J Clin 67: 122-137, 2017.

22. Martino R and Ringash J: Evaluation of quality of life and organ function in head and neck squamous cell carcinoma. Hematol Oncol Clin North Am 22: 1239-1256, 2008.

23. Soni M, Rahardjo TB, Soekardi R, Sulistyowati Y, Lestariningsih, Yesufu-Udechuku A, Irsan A and Hogervorst E: Phytoestrogens and cognitive function: A review. Maturitas 77: 209-220, 2014. 
24. Sirotkin AV and Harrath AH: Phytoestrogens and their effects Eur J Pharmacol 741: 230-236, 2014.

25. Qadir MI and Cheema BN: Phytoestrogens and related food components in the prevention of cancer. Crit Rev Eukaryot Gene Expr 27: 99-112, 2017.

26. Cho IA, You SJ, Kang KR, Kim SG, Oh JS, You JS, Lee GJ, Seo YS, Kim DK, Kim CS, et al: Biochanin-A induces apoptosis and suppresses migration in $\mathrm{FaDu}$ human pharynx squamous carcinoma cells. Oncol Rep 38: 2985-2992, 2017.

27. Huh JE, Nam DW, Baek YH, Kang JW, Park DS, Choi DY and Lee JD: Formononetin accelerates wound repair by the regulation of early growth response factor-1 transcription factor through the phosphorylation of the ERK and p38 MAPK pathways. Int Immunopharmacol 11: 46-54, 2011.

28. Huh JE, Seo DM, Baek YH, Choi DY, Park DS and Lee JD: Biphasic positive effect of formononetin on metabolic activity of human normal and osteoarthritic subchondral osteoblasts. Int Immunopharmacol 10: 500-507, 2010.

29. Hu W and Xiao Z: Formononetin induces apoptosis of human osteosarcoma cell line U2OS by regulating the expression of Bcl-2, Bax and MiR-375 in vitro and in vivo. Cell Physiol Biochem 37: 933-939, 2015.

30. Liu XJ, Li YQ, Chen QY, Xiao SJ and Zeng SE: Up-regulating of RASD1 and apoptosis of DU-145 human prostate cancer cells induced by formononetin in vitro. Asian Pac J Cancer Prev 15 2835-2839, 2014

31. Chen J, Zhao X, Ye Y, Wang Y and Tian J: Estrogen receptor beta-mediated proliferative inhibition and apoptosis in human breast cancer by calycosin and formononetin. Cell Physiol Biochem 32: 1790-1797, 2013.

32. Bortner CD and Cidlowski JA: Cell shrinkage and monovalent cation fluxes: Role in apoptosis. Arch Biochem Biophys 462 176-188, 2007.

33. Kass GE, Eriksson JE, Weis M, Orrenius S and Chow SC: Chromatin condensation during apoptosis requires ATP Biochem J 318: 749-752, 1996.

34. Higuchi Y: Chromosomal DNA fragmentation in apoptosis and necrosis induced by oxidative stress. Biochem Pharmacol 66 : $1527-1535,2003$

35. Chai F, Truong-Tran AQ, Ho LH and Zalewski PD: Regulation of caspase activation and apoptosis by cellular zinc fluxes and zinc deprivation: A review. Immunol Cell Biol 77: 272-278, 1999.

36. Pfeffer CM and Singh ATK: Apoptosis: A target for anticancer therapy. Int J Mol Sci 19: 448, 2018.

37. Zaman S, Wang $\mathrm{R}$ and Gandhi V: Targeting the apoptosis pathway in hematologic malignancies. Leuk Lymphoma 55: 1980-1992, 2014.

38. Goldar S, Khaniani MS, Derakhshan SM and Baradaran B: Molecular mechanisms of apoptosis and roles in cancer development and treatment. Asian Pac J Cancer Prev 16: 2129-2144, 2015.

39. Liu H, Su D, Zhang J, Ge S, Li Y, Wang F, Gravel M, Roulston A, Song Q, Xu W, et al: Improvement of pharmacokinetic profile of TRAIL via trimer-tag enhances its antitumor activity in vivo. Sci Rep 7: 8953, 2017.
40. Hassan M, Watari H, AbuAlmaaty A, Ohba Y and Sakuragi N: Apoptosis and molecular targeting therapy in cancer. Biomed Res Int 2014: 150845, 2014.

41. Green DR and Llambi F: Cell death signaling. Cold Spring Harb Perspect Biol 1: a006080, 2015.

42. Suhaili SH, Karimian H, Stellato M, Lee TH and Aguilar MI: Mitochondrial outer membrane permeabilization: A focus on the role of mitochondrial membrane structural organization. Biophys Rev 9: 443-457, 2017.

43. Czabotar PE, Colman PM and Huang DC: Bax activation by Bim? Cell Death Differ 16: 1187-1191, 2009.

44. Gogada R, Yadav N, Liu J, Tang S, Zhang D, Schneider A, Seshadri A, Sun L, Aldaz CM, Tang DG and Chandra D: Bim, a proapoptotic protein, up-regulated via transcription factor E2F1-dependent mechanism, functions as a prosurvival molecule in cancer. J Biol Chem 288: 368-381, 2013.

45. Zhang X, Bi L, Ye Y and Chen J: Formononetin induces apoptosis in $\mathrm{PC}-3$ prostate cancer cells through enhancing the $\mathrm{Bax} / \mathrm{Bcl}-2$ ratios and regulating the p38/Akt pathway. Nutr Cancer 66: 656-661, 2014.

46. Peng Q, Deng Z,Pan H, Gu L, Liu O and Tang Z: Mitogen-activated protein kinase signaling pathway in oral cancer. Oncol Lett 15: 1379-1388, 2018

47. Huang RH, Quan YJ, Chen JH, Wang TF, Xu M, Ye M, Yuan H, Zhang CJ, Liu XJ and Min ZJ: Osteopontin promotes cell migration and invasion, and inhibits apoptosis and autophagy in colorectal cancer by activating the p38 MAPK signaling pathway. Cell Physiol Biochem 41: 1851-1864, 2017.

48. Lv D, Wu H, Xing R, Shu F, Lei B, Lei C, Zhou X, Wan B, Yang Y, Zhong L, et al: HnR NP-L mediates bladder cancer progression by inhibiting apoptotic signaling and enhancing MAPK signaling pathways. Oncotarget 8: 13586-13599, 2017.

49. Chen $\mathrm{H}$, Jin $\mathrm{ZL}$ and $\mathrm{Xu} \mathrm{H}$ : MEK/ERK signaling pathway in apoptosis of SW620 cell line and inhibition effect of resveratrol. Asian Pac J Trop Med 9: 49-53, 2016.

50. Sun XF and Zhang H: NFKB and NFKBI polymorphisms in relation to susceptibility of tumour and other diseases. Histol Histopathol 22: 1387-1398, 2007.

51. Yap TA, Garrett MD, Walton MI, Raynaud F, de Bono JS and Workman P: Targeting the PI3K-AKT-mTOR pathway: Progress, pitfalls, and promises. Curr Opin Pharmacol 8: 393-412, 2008.

52. Alam M, Kashyap T, Pramanik KK, Singh AK, Nagini S and Mishra R: The elevated activation of NFkB and AP-1 is correlated with differential regulation of $\mathrm{Bcl}-2$ and associated with oral squamous cell carcinoma progression and resistance. Clin Oral Investig 21: 2721-2731, 2017.

53. Wu XY, Xu H, Wu ZF, Chen C, Liu JY, Wu GN, Yao XQ, Liu FK, Li $\mathrm{G}$ and Shen L: Formononetin, a novel FGFR2 inhibitor, potently inhibits angiogenesis and tumor growth in preclinical models. Oncotarget 6: 44563-44578, 2015.

54. Tyagi A, Gu M, Takahata T, Frederick B, Agarwal C, Siriwardana S, Agarwal R and Sclafani RA: Resveratrol selectively induces DNA damage, independent of Smad4 expression, in its efficacy against human head and neck squamous cell carcinoma. Clin Cancer Res 17: 5402-5411, 2011. 